\title{
Implementasi Program Moderasi Beragama yang Dicanangkan oleh Kementerian Agama Kabupaten Banyumas di Lingkungan Sekolah
}

\author{
Muhammad Nur Rofik ${ }^{1]}$, M. Misbah ${ }^{2]}$ \\ Universitas Islam Negeri Syaifuddin Zuhri Purwokerto \\ E-Mail: ${ }^{1]}$ semutrofik@gmail.com \\ ${ }^{2]}$ misbah@iainpurwokerto.ac.id
}

\begin{abstract}
Abstrak
Kemajuan zaman dan teknologi saat ini membuat segala informasi bisa diakses melalui media apapun termasuk hal yang berkaitan dengan pemahaman keagamaan di kalangan guru maupun siswa. Hal ini mempermudah akses oknum-oknum tertentu yang berniat untuk mendoktrin pikiran siswa dan guru menjadi radikalisme yang tidak toleran. Untuk itu perlu adanya program khusus dalam upaya menjaga dan melindungi siswa dari paham tersebut di lingkungan sekolah. Oleh karena itu, tujuan penelitian ini adalah untuk mendeskripsikan dan menganalisis langkah-langkah pencegahan paham radikalisme keagamaan yang intoleran di lingkungan sekolah. Penelitian ini adalah penelitian lapangan yang kemudian disajikan dalam bentuk deskriptif. Penelitian ini dilaksanakan dari tanggal 15 Maret 2021 sampai dengan 13 Juni 2021. Subjek dalam penelitian ini antara lain adalah Kepala Seksi PAI, Guru PAI di SD, SMP, SMA, dan SMK. Teknik pengumpulan data dari penelitian ini dilakukan dengan cara observasi, wawancara, dokumentasi, dan triangulasi. Pengolahan data dalam penelitian ini dilaksanakan dengan cara reduksi data, penyajian data, dan menarik kesimpulan atau verifikasi. Hasil penelitian ini menunjukkan bahwa Kementerian Agama Kabupaten Banyumas mengimplementasikan program moderasi beragama di lingkungan pendidikan sekolah dengan cara: 1) Kementerian Agama Kabupaten Banyumas sebagai Pembina Guru PAI, 2) Pembina Ekstrakulikuler Keagamaan, 3) Pengampu Guru PAI, 4) Pengawas Guru PAI, dan 5) Kementerian Agama juga bekerja sama dengan Forum Kerukunan Umat Beragama (FKUB) Kabupaten Banyumas. Kesimpulan dari penelitian ini bahwa program moderasi beragama yang dicanangkan oleh Kementerian Agama Kabupaten Banyumas di lingkungan sekolah sudah berjalan dengan cukup baik karena koordinasi yang baik antara Kementerian Agama Kabupaten Banyumas dengan Guru PAI di Sekolah.
\end{abstract}

Kata Kunci: Moderasi, Agama, Pendidikan, Guru, Siswa

\section{Implementation of Religious Moderation Program Launched by Ministry of Religion of Banyumas Regency in the School Environment}

\begin{abstract}
The progress of the times and current technology makes all information accessible through any media, including matters relating to religious understanding among teachers and students. This makes it easier to access certain elements who intend to indoctrinate the minds of students and teachers into intolerant radicalism. For this reason, it is necessary to have a special program in an effort to maintain and protect
\end{abstract}


students from this understanding in the school environment. Therefore, the purpose of this study is to describe and analyze the steps to prevent intolerant religious radicalism in the school environment. This research is a field research which is then presented in descriptive form. This research was carried out from March 15, 2021 to June 13, 2021. The subjects in this study included the Head of the PAI Section, PAI teachers in SD, SMP, SMA, and SMK. The data collection technique was by means of observation, interviews, documentation, and triangulation. Data analysis technique in this study was carried out by means of data reduction, data presentation, and drawing conclusions or verification. The results of this study indicate that the Ministry of Religion of Banyumas Regency implements a program of religious moderation in the school education environment by: 1) The Ministry of Religion of Banyumas Regency as a PAI Teacher Trustee, 2) Religious Extracurricular Trustees, 3) PAI Teacher Supervisors, 4) PAI Teacher Supervisors, and 5) The Ministry of Religion also cooperates with the Banyumas Regency Religious Harmony Forum (FKUB). The conclusion of this study is that the religious moderation program launched by the Ministry of Religion of Banyumas Regency in the school environment has been running quite well because of good coordination between the Ministry of Religion of Banyumas Regency and PAI teachers in schools.

Keywords: Moderation, Religion, Education, Teachers, Students

\section{PENDAHULUAN}

Indonesia adalah negara dengan mayoritas penduduk terbanyak beragama Islam di antara negara-negara yang ada di dunia. Hal ini menjadikan Indonesia sebagai negara yang paling sering disorot, terutama kaitannya dengan moderasi Islam. Moderasi adalah inti ajaran Islam. Islam yang moderat adalah ajaran agama yang syarat dengan keberagaman pada seluruh aspek, baik aspek agama, aspek adat, aspek suku, ataupun aspek bangsa (Dawing, 2017: 225).

Indonesia juga merupakan negara demokrasi, sehingga perbedaan pandangan dan kepentingan sering terjadi. Begitu juga dalam beragama, negara memiliki peran penting dalam menjamin keamanan masyarakat untuk memeluk dan menjalankan ajaran agamanya sesuai dengan apa yang diyakininya. Dalam perspektif Islam, di antara keberagaman agama, falsafah, maupun ideologi yang ada di dunia, hanya Islam yang menjadi agama paling mampu untuk bertahan dalam menyikapi tantangan zaman. Pendapat ini didasarkan pada realitas yang menunjukkan bahwa islam merupakan satu-satunya agama yang bersifat universal dan komprehensif. Kedua sifat inilah yang menjadikan keistimewaan ada dalam Islam (Amin, 2014: 23). Sifat Universal dan komprehensif ini yang saat ini lebih dikenal dengan istilah moderasi.

Fakta dan data keragaman agama agama di Indonesia menunjukkan bahwa keragaman agama ini merupakan mozaik yang memperkaya khazanah kehidupan keagamaan di Indonesia, namun di sisi lain keragaman agama juga mengandung potensi ancaman bagi persatuan Negara Republik Indonesia. Disinilah diperlukan keterlibatan seluruh warga masyarakat dalam mewujudkan kedamaian (Akhmadi, 2019: 48).

Untuk itu pemahaman perihal moderasi beragama harus dapat dimaknai secara holistik dan kontekstual bukan lagi tekstual. Maksudnya bahwa bukan memoderatkan Indonesia akan tetapi bagaimana cara kita memahami keberagaman dalam beragama dimana harus moderat dan menjunjung tinggi nilai-nilai toleransi. Sebab Indonesia 
merupakan negara multikultural yang terdiri dari beragam suku, budaya, dan adat istiadat yang penting untuk dijaga. Persoalan radikalisme keagamaan yang berujung pada konflik tentu sepantasnya tidak terjadi di Indonesia, mengingat Indonesia mempunyai semboyan "Bhinneka Tunggal Ika" atau berbedabeda tetapi tetap satu jua.

Namun sebelum membahas lebih dalam, perlu dipahami dulu apa sebenarnya moderasi yang dimaksud. Dalam bahasa Arab, istilah moderasi biasa dikenal dengan kata "wasath" atau "wasathiyyah"; orangnya disebut "wasith". Kata "wasit" telah menjadi kata serapan dalam bahasa Indonesia yang mempunyai tiga makna, yakni 1) orang yang mengenai pengantara (seperti dalam kegiatan perdagangan dan bisnis, serta lainnya), 2) orang yang melerai (pendamai) diantara orang yang berkonflik, dan 3) sosok pemimpin di tengah berlangsungnya pertandingan (Almu'tasim, 2019: 199).

Dari segi praktisnya, perwujudan sikap moderat atau mengambil jalan tengah dalam Islam dapat digolongkan menjadi empat wilayah pembahasan, yakni moderat dalam peihal problematika akidah, ibadah, perangai dan budi pekerti, dan permasalahan pembentukan syariat (Yasid, 2010). Sedangkan menurut Harin, moderasi akan selalu berdampingan dengan keseimbangan dan keadilan karena keduanya adalah prinsip dasar dari moderasi dalam beragama (Hiqmatunnisa \& Az-Zafi, 2020: 29).

Munculnya radikalisme keagamaan ini juga salah satunya diakibatkan oleh keyakinan yang berbeda dan adanya upaya untuk memenangkan perdebatan perihal pemaknaan kebenaran agama. Misalnya pemaknaan agama yang dianggap berbeda oleh pemeluk agama lain sehingga memunculkan konflik vertikal ataupun horizontal.

Hal semacam ini diduga berasal dari kemajuan pola pikir dan sudut pandang masyarakat tentang perkara agama yang semakin kompleks. Pola pemikiran tentang keagamaan adalah hal serius yang harus selalu diperhatikan karena dari pemikiran itulah yang menyebabkan kesalahpahaman dalam menangkap sebuah ajaran Islam yang relevan dengan quran ataupun hadis. Banyak dari masyarakat pada saat ini yang fanatik terhadap keyakinan model paham agama yang diyakininya. Inilah yang kemudian dikhawatirkan menjadikan sifat intoleran antar paham keagamaan yang lain.

Belakangan ini diskursus moderasi beragama semakin gencar disuarakan dan digaungkan oleh pemerintah mengingat berbagai macam konflik yang muncul ganti picu dipicu oleh persoalan kesalahpahaman keagamaan dalam realitas keragaman di indonesia. Selain daripada itu dengan menguatnya sebuah politik identitas daripada agama juga disinyalir dapat berpotensi memantik beragam persoalan sosial. Maka daripada itu sangat penting adanya sebuah transformasi pemikiran atau suatu sikap keberagamaan dengan jalan merubah pandangan keberagamaan yang eksklusif menuju pada suatu pandangan yang lebih inklusif dan pluralis. Secara etimologi moderasi beragama diterjemahkan dari kata wasathiyah islamiyah yang berarti seimbang, moderat, berada di tengah atau tidak condong pada paradigma kanan ataupun kiri di dalam beragama. Demikian secara terminologi pada umumnya moderasi beragama menurut Yusuf Qardhawi dimaknai sebagai sikap nyata dalam mengambil jalan tengah diantara dua jalan yang saling bertentangan atau berlebihan sehingga daripada kedua hal yang dimaksudkan tadi tidak mendominasi paradigma seseorang (Suharto, dkk: 2019).

Moderasi Islam dapat menjadi solusi dalam mengatasi berbagai persoalan kegamaan dan perdaban dunia. Yang menarik adalah muslim moderat mampu menghadapi kelompok radikal dengan cara yang santun dan damai. 
Adanya heterogenitas yang ada dalam bangsa Indoensia ini bisa disebut juga sunnatullah yang Allah berikan. Namun dalam perbedaan-perbedaan yang ada Allah tetap menjadikan satu kerangka kesatuan umat (Ummatan Wahidah). Maka dari itu dalam kehidupan nyata sebagai umat Islam kita dituntut untuk menjadi umat yang moderat (Ummatan Wasathiyyah). Namun kekhawatiran yang muncul adalah paham fanatisme yang bermunculan dari masyarakat yang tidak bisa diarahkan.

Moderasi Islam dipandang sebagai paham yang esensial. Sebuah ajaran yang memprioritaskan hubungan terhadap alam, hubungan terhadap manusia (baik saudara seiman maupun beda keyakinan), dan hubungan terhadap tuhan (Kementerian Agama RI, 2015).

Paham tersebut yang kemudian memasuki lingkungan pendidikan yang dibawa oleh pendidik maupun peserta didik. Kemudian yang perlu diwaspadai adalah hal semacam ini bisa membuat sebuah keretakan dalam intern Agama Islam itu sendiri.

Dalam menyikapi masyarakat yang beragam dan menghidari terjadinya radikalisme adalah dengan pendidkan islam moderat maupun pendidikan inklusif (Alam, 2017: 36).

Jika menoleh kebelakang asal mula konflik kemasyarakatan bersumber dari islam kiri (komunis) dan islam kanan (islamisme). Akan tetapi saat ini ancaman dis-harmoni seringkali muncul dari pengaruh globalisasi yang dapat disebut sebagai dua fundamentalisme yaitu pasar dan agama (Latif, 2014: 251).

Dalam realita kehidupan sosok manusia tidak lepas dari problematika yang bertentangan. Untuk itu, islam wasathiyah menjunjung tinggi aspek ketuhanan (rabaniyah) dan aspek kemanusiaan (insaniyah), memadukan antara materialisme (maddiyah) dan spiritualisme (ruhhiyah), menggabungkan antara wahyu dan akal, maslahah ammah dan maslahah individu (Almu'tasim, 2019:
212).

Sikap beragama yang menempatkan dirinya dalam posisi tengah dan seimbang merupakan pemahaman dari moderasi. Keseimbangan diperlukan agar tidak terjadi collaps di salah satu pihak antara pengalaman pada agama yang dianutnya serta penghormatan kepada keyakinan yang dianut orang lain. Sikap moderat ini menafikan kita kepada sikap yang terlampau ekstrem dan fanatik dalam beragama. Moderasi beragama diibaratkan pemisah antara kutub konservatif dengan kutub liberal.

Terciptanya kerukunan dan perdamaian global diawali dengan sikap moderasi individu. Jatuhnya pilihan kepada moderasi merupakan salah satu upaya menolak tindakan - tindakan tidak manusiawi, karena moderat mengedepankan prinsip kedamaian. Melalui cara ini maka manusia satu dengan lainnya dapat memperlakukan sesamanya secara terhormat, menerima segala jenis perbedaan, serta mampu menciptakan harmoni damai dalam keberagaman (Wahyudi \& Novita, 2021: 28).

Adapun ciri-ciri tentang wasathiyyah sebagai berikut:

1. Tawassuth (bersikap tengah), merupakan sikap dan cara pandang yang tidak fanatik terhadap suatu hal, akan tetapi memposikan diri di tengah diantara perbedaan dalam ajaran agama.

2. Tawazun (seimbang), yakni memahami dan menagamalkan ajaran agama dengan cara yang seimbang, baik seimbang antara dunia dan akhirat, maupun bersikap tegas dalam menyikapi penyimpangan dan perbedaan

3. I'tidâl (lurus dan tegas), adalah memposisikan sesuatu sebagaimana mestinya dan menjalankan hak dan kewajiban dengan profesional.

4. Tasamuh (toleransi), adalah sikap menghargai dan menghormati keragaman dan perbedaan agama maupun aspek kehidupan yang lainnya. 
5. Musawah (egaliter), merupakan sikap non-diskriminatif terhadap yang lain karena adanya perbedaan adat, budaya, keyakinan maupun asal muasal seseorang.

6. Syura (musyawarah), adalah cara menyelesaikan persoalan dengan prinsip mencari kesepakatan bersama tanpa mementingkan kepentingan salah satu golongan.

7. Ishlah (reformasi), adalah sikap yang kuat untuk melakukan perubahan untuk kemajuan zaman dan memegang teguh nilai kemaslahatan bersama dan almuhafazhah 'ala al-qadimial-shalih wa al-akhdzu bi al-jadidi al-ashlah (mempertahankan tradisi lama yang masih relevan, dan menerapkan halhal baru yang lebih relevan)

8. Aulawiyah

(mengutamakan prioritas), adalah keterampilan menganalisis hal yang lebih penting daripada kurang penting.

9. Tathawwur wa Ibtikar adalah sikap terbuka dalam melaksanakan perubahan ke arah yang lebih baik selalu terbuka untuk melakukan perubahan-perubahan kearah yang lebih baik (dinamis dan inovatif) (Nur \& Mukhlis, 2016).

Dalam penelitian ini, peneliti lebih tertatik membahas isu moderasi beragama ini pada lingkungan sekolah. Mengingat banyaknya data dan informasi yang beredar, bahwa paham radikalisme keagamaan sudah merasuk ke dalam pikiran siswa yang mereka dapat melalui media dan yang sejenisnya.

Media elektronik yang canggih di zaman ini. Kurangnya rasa keingintahuan akan pembenaran data atau informasi keagaaman yang mereka dapat sehingga menimbulkan kekacauan dalam bertindak. Seperto sebuah riset yang dilakukan PPIM UIN Jakarta (2017) terhadap siswa atau mahasiswa serta guru maupun dosen dari 34 provinsi di Indonesia yang menunjukkan bahwa sejumlah $34,3 \%$ responden mempunnyai pandangan intoleransi terhadap agama yang tidak seiman (non islam).
Kemudian, ditambah lagi data yang cukup memprihatinkan sejumlah 48,95\% responden siswa/mahasiswa menyatakan bahwa pendidikan agama yang mereka dapat cenderung menimbulkan sikap tidak suka bergaul agama yang tidak seiman. Terlebih yang mengejutkan lagi adalah sejumlah $58,55 \%$ responden mahasiswa/siswa mempunyai pemikiran keagamaan yang radikal dan fanatik. Artinya ia hanya membenarkan apa yang ia pahami dan tidak sepakat dengan pemahaman lain (PPIM UIN Jakarta, 2017).

Banyaknya persoalan dalam menemukan sintesa terbaik sebagai umat yang moderat tentu bukan persoalan mudah. Hal ini dikarenakan sikap moderat tidak hanya ditujukan kepada lingkungan internal Islam, akan tetapi juga dengan masyarakat di luar Islam. Melacak gambaran sikap moderat yang diajarkan oleh Islam tentu harus merujuk kepada pegangan utama Islam yakni, Al-Qur'an dan Hadits Nabi Muhammad Shallallahu 'Alaihi Wasallam (Zamimah, 2018: 78).

Moderasi beragama di Indonesia sebagai upaya dalam mengantisipasi paham radikal sebab Islam moderat merupakan yang paling cocok bagi Indonesia yang memiliki keberagaman. Moderasi beragama menjadi penting untuk siswa di lingkungan sekolah maupun mahasiswa di tingkat kampus sebagai generasi penerus memajukan bangsa dimasa datang, penanaman nilai-nilai Islam moderat perlu diupayakan sebagai upaya mencegah terpapar paham radikalisme. Langkah konkrit dalam memberikan nilai-nilai moderasi beragama pada generasi muda adalah melalui pendidikan agama (Purwanto, dkk: 2019).

Tidak sedikit riset yang dilakukan oleh berbagai lembaga pendidikan perihal intoleransi, anti-kebinekaan, dan radikasilme yang merambah ke lingkungan sekolah dan juga madrasah. Secara umum, lembaha cenderung sepakat jika radikalisme dapat masuk ke lingkungan sekolah melalui: sosok guru dalam memandu peserta didik dalam kegiatan 
pembelajaran, bahan ajar yang diduga mengandung konten intoleransi, kuatnya doktrin dari alumni dalam aktivitas kesiswaan yang dilakukan di sekolah maupun di luar sekolah dan kegiatan intra atau ekstrakulikuler seperti Rohani Islam (rohis) serta tidak kuatnya kebijakan sosok kepala sekolah dalam mengantisipasi masuknya paham radikalisme ke lingkungan sekolah.

Padahal pendidikan seharusnya berpengaruh pada nilai -nilai moderasi beragama pada siswa yang di dapatkan dari berbagai sumber Literasi, pengalaman pribadi, lingkungan madrasah, lingkungan keluarga, guru yang memberikan pendidikan dan pengajaran tentang keragaman (Salim, 2012:24).

Melihat fenomena tersebut, Kementerian Agama selaku pemangku kebijakan dan penanggung jawab dalam persoalan keagamaan yang terjadi tentu tidak bisa tinggal diam melihat fenomena yang ada. Maka akhirnya Kementerian Agama menggaungkan program moderasi beragama.

Untuk itu, dalam penelitian ini berusaha menjawab rumusan masalah, Bagaimana Implementasi Program Moderasi Beragama di Kementerian Agama Kabupaten Banyumas di Lingkungan Sekolah?

Adapun tujuan daripada penelitian ini adalah untuk menjadikan keberagaman agama sebagai hal yang bisa berjalan seiring dan seimbang khususnya di lingkungan sekolah.

\section{METODE}

Penelitian ini merupakan penelitian kualitatif dengan menggunakan paradigma pospositivisme, atau lebih dikenal dengan induktif (pembahasan khusus ke umum). Paradigma penelitian dilaksanakan melalui beberapa tahap induktif seperti mengkonsep, mengkategorisasi, serta menghadirkan gambaran yang dikembangkan atas dasar permasalahan yang terdapat di lapangan.
Penelitian ini berangkat dari konsep khusus yaitu mulai dari konsep Kementerian Agama Banyumas dalam memberikan pembinaan keagamaan kepada guru sekolah, terkhususkan guru agama di sekolah yang dinaunginya serta pembinaan kepada siswa terkait implementasi moderasi beragama.

Adapun prosedur yang dilakukan pada penelitian ini: 1) Peneliti melakukan observasi awal untuk mencari informasi terkait topik penelitia di Kantor Kementerian Agama Kabupaten Banyumas, 2) Peneliti melakukan wawancara dengan Kepala Seksi PAI yang bertanggung jawab terhadap Guru PAI di sekolah, 3) Peneliti melakukan wawancara dengan Guru PAI di setiap jenjang sekolah, 4) Peneliti meminta dokumen kegiatan program moderasi beragama di sekolah, 5) Peneliti menyusun hasil penelitian.

Dalam penelitian ini, peneliti mewawancarai Kasi PAI di Kementerian Agama Kabupaten Banyumas dan 1 (satu) guru PAI di setiap jenjang sekolah dari mulai Sekolah Dasar (SD), Sekolah Menengah Pertama (SMP), Sekolah Menengah Atas (SMA), dan Sekolah Menengah Kejuruan (SMK) untuk memverifikasi kegiatan-kegiatan yang dilakukan oleh Kementerian Agama Kabupaten Banyumas.

Penelitian ini dilaksanakan di Kantor Kementerian Agama Banyumas, yang beralamat di Jl. Mayor Jenderal D.I. Panjaitan, 483, Kedung ampel, Purwokerto Wetan, Kecamatan Purwokerto Timur, Kabupaten Banyumas, Jawa Tengah.

Penelitian ini dilaksanakan dari tanggal 15 Maret 2021 sampai dengan 13 Juni 2021. Instrumen Pengumpulan data dari penelitian ini adalah lembar observasi, wawancara, dan dokumentasi. Pengolahan data dalam penelitian ini dilaksanakan dengan cara reduksi data, penyajian data, dan menarik kesimpulan atau verifikasi. 


\section{HASIL DAN PEMBAHASAN}

Dalam penelitian yang dilaksanakan kurang lebih 3 bulan ini, peneliti berusaha mencari dan menganalisis bagaimana progam moderasi beragama oleh Kementerian Agama Kabupaten Banyumas ini diimplementasikan di lingkungan sekolah. Selanjutnya, hasil wawancara peneliti dengan responden dalam penelitian ini dapat dilihat pada Tabel 1 berikut.

Tabel 1. Hasil Wawancara Peneliti
dengan Responden

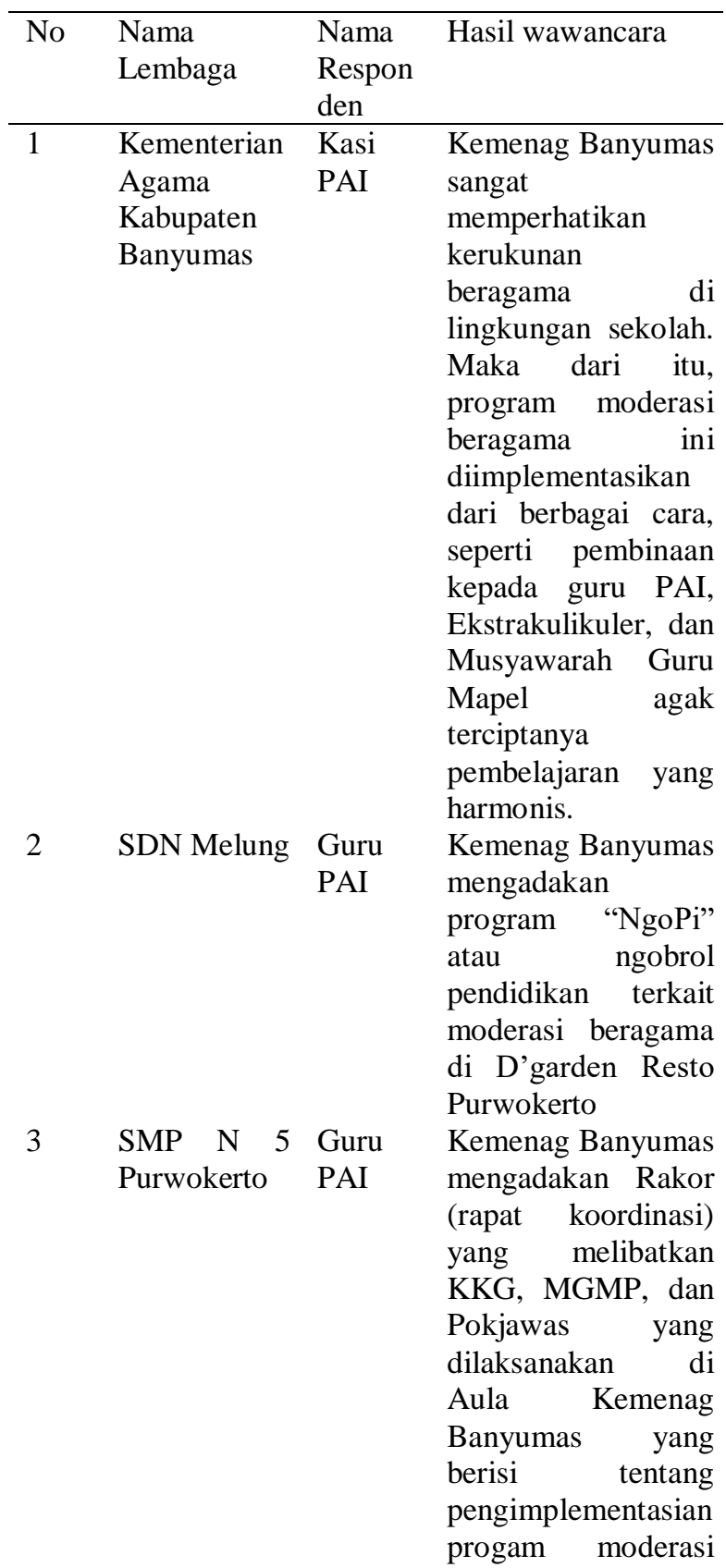

Tabel 1 di atas merupakan penjelasan secara ringkas dari hasil wawancara dengan responden. Adapun penjelasan lebih detail dari hasil penelitian ini dapat dijelaskan pada sub pembahasan berikut.

\section{a. Kebijakan Kementerian Agama Kabupaten Banyumas dalam mengimplementasikan moderasi beragama di sekolah}

Kementerian Agama Kabupaten Banyumas sangat serius dalam menggarap program moderasi beragama. Hal ini diacu kepada Keputusan Menteri Agama (KMA) Republik Indonesia Nomor 328 Tahun 2020 tentang Kelompok Kerja Penguatan Program Moderasi Beragama Pada Kementerian Agama. Di dalamnya dituliskan bahwa tugas Kelompok Kerja Penguatan Program Moderasi Beragama memiliki tugas: 1) Mengkoordinasikan 
perumusan dan menetapkan pelaksanaan program penguatan program moderasi beragama, 2) Memberikan arahan dan penyusunan rencana aksi pelaksanaan penguatan program moderasi beragama, 3) Merancang rencana aksi atau tindak lanjut pelaksanaan penguatan program moderasi beragama, 4) Mengendalikan pelaksanaan rencana aksi atau tindak lanjut pelaksanaan penguatan program moderasi beragama, 5) Melakukan pemantauan dan mengevaluasi pelaksanaan penguatan program moderasi beragama, 6) Melakukan koordinasi dengan kementerian dan lembaga dalam pelaksanaan penguatan program moderasi beragama, 7) Melaporkan pelaksanaan tugas kepada Menteri Agama (KMA No. 328 Tahun 2020).

Selain dibuatkannya KMA Nomor 328 Tahun 2020, bukti keseriusan Kementerian Agama dalam merealisasikan program moderasi beragama adalah dengan dimasukannya program tersebut dalam Rencana Pembangunan Jangka Menengah Nasional (RPJMN) 2020-2024.

Bahkan untuk menguatkan moderasi beragama, Kementerian Agama berupaya meluncurkan Program Pengembangan Keprofesian Berkelanjutan Guru Pendidikan Agama Islam (PPKB GPAI). Tujuan utama direalisasikannya PPKB GPAI ini adalah sebagai program penguatan moderasi beragama dan meningkatnya kompetensi guru PAI.

Dalam Peraturan Menteri Agama Nomor 16 tahun 2010 tentang Pengelolaan Pendidikan Agama pada sekolah Bab VI pasal 16, terdapat lima kompetensi yang harus melekat dalam guru PAI, diantaranya: 1) Kompetensi Pedagogis, 2) Kompetensi Kepribadian, 3) Kompetensi Sosial, 4) Kompetensi Profesional, dan 5) Kompetensi Kepemimpinan (PMA No.16 Tahun 2010).

\section{b. Perencanaan Program Moderasi Beragama Kementerian Agama Kabupaten Banyumas di sekolah}

Dengan beragamnya ras, suku, bahasa, dan juga agama yang dimiliki oleh Indonesia lembaga pendidikan sangatlah tepat ketika menjadi laboratorium moderasi beragama bagi generasi saat ini. Karena di sekolah inilah tempat para peserta didik mendapatkan hal baru, mempelajari hal baru dan saling bertukar pikiran antara satu dengan yang lainnya (Sutrisno, 2019: 341).

Dengan proses pembelajaran yang dilakukan oleh peserta didik pasti akan menumbuhkan pola pikir tidak hanya terkait mata pelajaran saja, namun pola pikir terhadap keyakinan yang dimiliki yang kemudian berbenturan dengan keyakinan yang dimiliki oleh siswa lainnya yang akan menumbuhkan ruang diskusi diantara keduanya. Dari sinilah bibit-bibit radikalisme dan fanatisme yang berlebihan terhadap keyakinannya ketika tidak segera diberi pemahaman tentang moderasi beragama (Ma'arif, 2012: 121).

Di dalam buku yang dipublikasikan di Maarif Institute, mempertahankan tembok kebhinekaan di lembaga pendidikan, meninjau dari 3 jalan inti bagaimana radikal serta rasa tidak menghargai satu sama lain melakukan penetrasi dalam lingkup sekolah ialah aktifitas tambahan kegiatan diluar jam pembelajaran, peran pendidik dikegiatan belajar dan pengajaran, melewati kebijakan lembaga sekolah yang renta dalam mengatur masuknya radikalisme di sekolah. Dari data tersebut perlakuan intoleran serta meningginya radikalisme dalam sekolah sudah tidak bisa dianggap remeh. Maka dari itu, diperlukannya moderasi beragama harus dilaksanakan.

Ruang kelas digunakan untuk menyampaikan gagasan kenegaraan, menerapkan nilai-nilai multikulturalisme, menyampaikan ajaran agama secara damai, serta menyebarkan kasih sayang kepada sesama manusia. Ini semua bersumber pada kurikulum yang berlandaskan pada moderasi beragama.

Berbeda dengan madrasah yang semua diisi oleh peserta didik yang 
beragama Islam, sekolah diharapkan menjadi tempat mengenalkan keberagaman agama yang ada di negara indonesia dan juga memperkenalkan apa itu Nahdlatul Ulama (NU) serta Muhammadiyah, kepada sekolah baik itu negeri maupun swasta yang ikut dalam kegiatan dalam organisasi masyatakat itu. Sebenarnya, manusia sudah memiliki pola sosial yang kokoh, keberagaman dalam bermasyarakat menjadi ciri khas indonesia. Nahdlatul Ulama (NU) serta Muhammadiyah merupakan ormas islam yang moderat di NKRI, harus bergerak mencari posisi dikarenakan mulai terkikis karena pengaruh dari pemikiran transnasional yang ingin mengubah sistem politik yang ada di NKRI.

Terdapat beberapa cara terbaik yang dapat dilakukan oleh pemerintah yaitu:
1. Moderasi
beragama
wajib

dipertimbangkan oleh pemerintah dalam upaya pembentukan (RPJPN) rencara pembangunan jangaka panjang nasional, ini adalah tugas pemerintah dalam penerapan moderasi beragama dalam kemajemukan agama agama di NKRI.

2. Menyertakan peranan lembaga pendidikan: seperti contohnya sekolah, madrasah dan juga pesantren atau tingkat yang lebih tinggi setingkat universitas atau pun juga dengan menyertakan lembaga non formal yang didalamnya terdapat asas kemanusiaan, toleransi beragama, serta moderasi beragama.

3. Meningkatkan literasi keagamaan (religious literacy) serta pndidikan lintas iman (interfaith education).

4. Lembaga pendidikan semestinya lebih aktif dalam penerapan aktifitas keagamaan yang bervariasi antar umat beragama lainnya.

Sejalan dengan penjelasan di atas, pembelajaran semestinya mampu meningkatkan teknik pembelajaran yang bertumpu pada standar kompetensi serta kompetensi dasar. Pemenuhan setiap KD kegiatan terpuji bisa diterapkan dalam pemakaian nilai-nilai agama.

Fungsi setiap unsur sekolah, wali murid serta masyarakat diperlukan guna menunjang tercapainya tujuan dari moderasi beragama di lembaga pendidikan.

Perencanaan program moderasi beragama oleh kementerian agama kabupaten banyumas di lingkungan sekolah sudah sangat matang dipersiapkan. Melihat situasi kerukunan yang ada di banyumas, kementerian agama kabupaten banyumas yakin bahwa program ini bisa berjalan dengan baik dan maksimal. Terlebih jika implementasinya adalah di lingkungan sekolah, maka sudah sepantasnya program ini harus dipersiapkan dengan sematang-matangnya dengan cara koordinasi yang baik antara pihak kemenag banyumas, guru PAI di sekolah, dan juga siswa.

\section{c. Pelaksanaan Program Moderasi Beragama Kementerian Agama Kabupaten Banyumas di Sekolah}

Secara kelembagaan pendidik mata pelajaran PAI yang mengajar di lembaga pendidikan (sekolah) adalah naungan Kementerian Pendidikan Kebudayaan Ristek dan Teknologi (Kemendikbudristek), namun pembinaan kepada guru PAI dilakukan oleh Kementerian Agama. Kementerian Agama Kabupaten Banyumas melalui seksi Pendidikan Agama Islam melakukan banyak program terkait pengejawantahan moderasi beragama di lingkungan sekolah. Banyak program yang telah diimplementasikan oleh Kementerian Agama Kabupaten Banyumas di lingkungan sekolah dalam mensukseskan penerapan moderasi beragama. Dari hasil observasi, wawancara dan juga penyatuan data yang didapat dari beberapa narasumber penelitian, maka dapat disimpulkan implementasi yang dilakukan Kementerian Agama Kabupaten Banyumas terhadap penerapan moderasi beragama di lingkungan sekolah sebagai berikut. 
Kementerian Agama Kabupaten Banyumas sebagai Pembina Guru Pendidikan Agama Islam (PAI) di sekolah

Strategi pendidikan serta pelatihan adalah aktifitas yang penting dalam SDM yang diperlukan ketika berhadapan dengan instansi, baik dari masa sekarang ataupun masa kedepannya (Nababan, 2016: 45).

Pelaksanaan pembinaan kepada guru merupakan hal yang wajib dilakukan dalam rangka peningkatan profresionalisme guru. Hal ini sesuai dengan target seksi PAI Kementerian Agama Kabupaten Banyumas no. 1 yaitu "peningkatan profesionalisme tenaga pendidik dan tenaga kependidikan agama Islam". Banyak cara dan metode yang dilakukan dalam rangka peningkatan profesionalitas guru khususnya berkaitan dengan implementasi moderasi beragama antara lain:

a) Workshop atau Diklat bahan penyusunan kurikulum

b) Workshop atau Diklat Penyusunan Materi Bahan Ajar

c) Workshop atau Diklat Pembuatan Soal HoTS (Higher Order Thinking Skills)

d) Workshop atau Diklat Penilaian dan evaluasi pembelajaran

Semua Workshop ataupun diklat yang dilaksanakan selalu dikaitkan dengan program moderasi beragama kementerian agama kabupaten banyumas. Itu semua bertujuan supaya kegiatan belajar mampu dilakukan dengan maksimal dan memunculkan toleransi yang kokoh.

Walaupun secara kelembagaan guru PAI di sekolah dibawah naungan Kemendikbudristek, namun guru PAI di sekolah mendapatkan bimbingan dibawah naungan Kementerian Agama (kemenag).

Berdasarkan wawancara dengan Bapak Amin Makruf selaku Guru PAI di SMA N 1 Purwokerto bahwa pelaksanaan diklat-diklat dari Kementerian Agama Kabupaten Banyumas diselaraskan dengan isi kandungan moderasi beragama. Sebagai contoh dalam diklat pembuatan soal, seluruh guru dibekali agar soal tersebut tidak berisi tentang perbedaan khilafiyah di dalam 1 (satu) agama misalnya soal lebih condong membenarkan kepada Organisasi Nahdlatul Ulama, atau soal lebih condong kepada Organisasi Muhammadiyah, dan sebagainya. Sekaligus bahwa soal yang dibuat tidak boleh ada istilah pengkafiran terhadap penganut agama lain yang bisa saja membuat ketidakharmonisan antara siswa muslim dengannon muslim.

Diklat yang diikuti oleh peserta yang banyak biasanya ditempatkan di Aula MAN 2 Banyumas, D'garden resto, ataupun di aula hotel yang memadai. Namun jika skala pesertanya sedikit biasanya dilaksanakan di beberapa ruang kelas yang digabung menjadi satu ruangan. Kemudian pembinaan yang sifatnya rutin 1 bulan 1 kali yaitu melalui kegiatan Rapat Koordinasi (Rakor) guru PAI sekolah yang bertempat di Aula Kementerian Agama Kabupaten Banyumas.

Pembinaan lain yang juga diadakan oleh Kementerian Agama Kabupaten Banyumas kepada guru - guru PAI adalah Diklat Bedah Standar Kompetensi Lulusan (SKL), bedah kurikuilum, dan juga penyeleksian buku bahan ajar. Menurut wawancara yang dilakukan peneliti dengan Bapak Wahidin selaku guru di SMK N 1 Kalibagor bahwa beliau sudah pernah mengikuti banyak diklat yang diadakan oleh Kementerian Agama Kabupaten Banyumas. Beliau menjelaskan bahwa dilaksanakannya diklat bedah SKL, Kurikulum, dan juga penyeleksian buku, guru PAI yang ada di sekolah menjadi lebih memahami materi -materi yang hendak disampaikan kepada siswa haruslah memuat sikap moderasi karena beragamnya agama yang dianut di SMK N 1 Kalibagor. Buku buku paket maupun Lembar Kerja Siswa (LKS) yang diberikan kepada siswa juga diteliti dan dikaji ulang jangan sampai memuat ajaran radikalisme. Dari pembinaan ini guru menjadi lebih memahami cara membuat soal yang benar dan mengkoreksi kesalahan pada buku yang hendak diajarkan. 
Kementerian Agama Kabupaten

Banyumas sebagai Pembina kegiatan Ekstrakulikuler Keagamaan di Sekolah

Dalam PP RI No. 55 Tahun 2007 mengenai pendidikan agama dan pendidikan keagamaan menjelaskan mengenai pengurusan pendidikan agama dilakukan oleh menteri agama, serta tujuannya ialah mengembangkan kualitas siswa dalam pemahaman, menjiwai, membagikan nilai-nilai agama serta menggabungkannya dengan ilmu pengetahuan dan juga teknologi serta seni.

Selanjutnya, dalam Peraturan Menteri Agama RI. No. 16 Tahun 2010 mengenai Pengelolaan pendidikan agama dalam lembaga pendidikan, dapat didimasukan ke dalam kegiatan diluar aktifitas pembelajaran biasa, atau bisa dimasukan ke intrakurikuler atau ekstrakulikuler contohnya seperti perlombaan. Salah satunya aktifitas ekstrakulikuler ialah sebagai berikut.

\section{Ekstrakurikuler Rohani Islam (Rohis)}

Rohis merupakan kegiatan keagamaan islam yang dilakukan oleh peserta didik dalam lingkup sekolah, yang dinaungi oleh salah satu organisasi yang ada disekolah yaitu OSIS.

Aktifitas rohis yang ada disekolah ialah: 1) Mabit, ialah aktifitas yang ditujukan untuk saling mengakrabkan sesama anggota yang dilakukan dari maghrib sampai subuh, 2) diskusi atau bedah buku (mujahadah), aktifitas ini dilakukan untuk memperdalam pengetahuan, melebarkan pemikiran dan juga membenarkan pengetahuan, 3) Daurah atau pelatihan, ialah aktifitas melatih peserta didik dalam membaca AlQuran, 4) penugasan, diberikan kepada siswa dalam bentuk hafalan suratan yang ada didalam Al Quran, 5) mentoring yaitu dilakukan oleh mentor, yang bertujuan untuk memberikan siraman rohani dan juga membahas ilmu pengetahuan yang mengerucuk ke agama sekarang. Jika disambungkan dengan mentoring islam, maka mentoring islam adalah jalan yang digunakan dalam menyebarkan tarbiyah Islamiyah (pendidikan pembinaan Islami) yang di dalamnya ada proses belajar.

Perwujudan moderasi beragama di sekolah melalui kegiatan rohis ini akan sangat representatif dilaksanakan terlebih kepada siswa. Melihat program kegiatan rohis yang telah dijelaskan di atas maka sangatlah tepat ketika penyampaian materi moderasi beragama disisipkan disetiap kegiatannya. Siswa dan siswi akan lebih mudah memahami apa makna moderasi beragama bagi dirinya kepada orang lain.

Kegiatan rohis menjadi sarana tarbiyah untuk membina ruhiyah, melembutkan hati, membersihkan jiwa, dan membiasakan fisik untuk beribadah (khususnya shalat tahajjud, dzikir, tadabbur dan tafakkur. Kegiatan ini diisi dengan pembekalan materi tentang keimanan, ibadah, tadarus Al- Qur'an, sholat wajib, sholat lail, pergaulan remaja dan bahaya narkoba.

Misalnya saja, dalam pelaksanaan setiap kegiatan yang dilakukan oleh Rohis di SMA N 1 Purwokerto tersebut baik Live in maupun MABIT selalu mendapatkan arahan dan pengawasan dari Kementerian Agama Kabupaten Banyumas bahwa dalam setiap materi yang disampaikan dalam kegiatan tersebut haruslah memuat materi moderasi beragama. Biasanya jika ada salah seorang pejabat kantor Kementerian Agama Kabupaten Banyumas yang berkenan hadir maka beliaulah yang menyempaikan materi moderasi beragama, namun jika semuanya berhalangan maka hanya diberikan materi moderasi beragama yang nantinya disampaikan oleh guru pembina rohis tersebut. Hal ini dilakukan untuk menjaga penyampaian materi yang terkontradiksi radikal kepada organisasi tertentu saja.

\section{Pentas PAI}

Kementerian Agama Kabupaten Banyumas juga ikut mengadakan kegiatan ekstrakulikuler keagamaan unggulan untuk peningkatan mutu siswa dalam bentuk Kegiatan Pekan Keterampilan dan Seni 
Pendidikan Agama Islam (Pentas PAI). Kegiatan ini dilaksanakan untuk semua jenjang dari mulai SD, SMP, SMA, dan SMK. Perlombaan ini diadakan mulai dari tingkat kecamatan, kabupaten, provinsi sampai dengan nasional.

Tujuan dari pelaksanan pentas PAI ini adalah sebagai berikut: 1) menaikan pemahaman serta kefokusan siswa mengenai pembelajaran islam yang mampu diterapkan dalam kesehariannya, 2) menyemangati siswa supaya lebih berkeinginan mendalami materi PAI, 3) membandingkan kesuksesan penggunaan PAI dalam sekolah yang dilihat dari pengetahuan, penjiwaan, pendalaman serta pengalaman ajaran islam, 4) menguatkan persodaraan antar umat islam serta satu sama lain antar siswa, 5) memuntulkan keinginan, kemampuan, dan juga imajinasi dalam bidang keterapilan dan seni PAI, 6) memasukan sifat berani, mandiri serta kejujuran kepada setiap peserta didik, 7) menambah keimanan, tunduk kepada Tuhan YME, serta berperilakubaik.

Kementerian Agama Kabupaten Banyumas pernah mengadakan kegiatan pentas PAI tingkat kabupaten yang diikuti 154 peserta dari jenjang SD, SMP, SMA dan SMK Tahun 2019 di d'Garden Hall \& Resto. Peserta pemenang disetiap jenis lomba akan mewakili Kabupaten Banyumas dalam pagelaran Pentas PAI tingkat Provinsi Jawa Tengah di Donohudan Solo.

\section{Kementerian Agama Kabupaten Banyumas sebagai Pengampu Guru PAI di Sekolah}

Dalam UU RI no. 14 Tahun 2005 mengenai Guru dan Dosen, memberikan persyaratan kepada guru supaya memiliki kualifikasi akademik minimum S1/D4, terdapat kriteria menjadi seorang pendidik yaitu kemampuan pedagogik, dan memiliki sertifikat pendidik (UU RI No. 14 Tahun 2005 tentang Guru dan Dosen).

Dengan adanya UU ini menjadi harapan dan juga memberi peluang kepada pendidik dalam memaksimalkan kemampuan dirinya dengan jalan pendidikan, pelatihan, memiliki karya ilmiah, aktif alam kegiatan kelompok maupun organisasi profesi guru serta pengawas, misalnya seperti Forum Komunikasi Guru (FKG), Pendidikan Agama Islam(PAI), untuk jenjang TK, dan banyak lainnya. Organisasi ini merupakan kelompok guru ataupun musyawarah guru yang bertujuan sebagai wadah untuk pengembangan profesionalisme guru.

Kegiatan pertemuan ini diharapkan mampu menjadi tempat saling bertukar ide atau pikiran, dan menyelesaikan permasalahan yang berkaitan dengan mata pelajaran PAI seperti pembuatan soal, review buku paket atau $1 \mathrm{ks}$, serta evaluasi pembelajaran yang semuanya ini selalu dikaitkan dengan implementasi program moderasi beragama.

Berdasarkan wawancara dengan Bapak Agus Setiawan bahwa Kementerian Agama Kabupaten Banyumas melalui seksi PAIS mengapresiasi adanya KKG dan MGMP karena bisa menjaga dan memperkuat ikatan antar sesama guru PAI agar senantiasa bisa sejalan dan sepaham dalam menyampaikan pembelajaran PAI kepada siswa. Melalui organisasi ini pula Kementerian Agama Kabupaten Banyumas selalu memberikan himbauan terkait proses pembuatan dan penyampaian materi haruslah bermuatan moderasi beragama.

Ini menjadi penting karena untuk menghilangkan stigma pada zaman sekarang yang menilai orang Islam itu teroris. Padahal ajaran asli agama Islam di dalam Al-AQur'an maupun hadits tentang keberagaman adalah merupakan rahmat serta menjaga kesatuan dan menghilangkan sikap permusuhan adalah ciri orang Islam sejati.

Kemudian ada forum atau organisasi profesi yang dibuat untuk semua guru PAI yaitu Asosiasi Guru Pendidikan Agama Islam Indonesia (AGPAII) dengan tujuan profesionalisme guru. Berdasarkan wawancara dengan Bapak Wahidin bahwa Kementerian Agama Kabupaten Banyumas pernah mengadakan Seminar tentang 
pegarusutamaan moderasi beragama bersama AGPAII pada tahun 2019. kegiatan ini diikuti oleh guru PAI di semua jenjang yang salah satunya adalah pentingnya pemahaman moderasi beragama kepada siswa.

\section{Kementerian Agama Kabupaten Banyumas sebagai Pengawas PAI di Sekolah}

Dalam Peraturan Menteri Agama Republik Indonesia No. 2 Tahun 2012 mengenai pengawas madrasah dan oengawas pendidikan agama islam pada sekolah bertujuan agar mampu memaksimalkan kemampuan pendidik dan juga pengawas madrasah serta pengawas PAI di sekolah dan juga keefektifitas pengawasan. Pengawas PAI memiliki naungan ketika sedang melakukan tugas dan kegunaannya yang dinamakan (POKJAWAS) Kelompok Kerja Pengawas.

Kementerian Agama Kabupaten Banyumas seringkali mengumpulkan Pengawas PAI di semua jenjang untuk keselarasan visi, misi, dan tujuan serta selalu memahami bahwa tujuan utama pengawas adalah membina, membimbing, dan juga menjadi teman yang baik bagi semua guru PAI agar semua problematika yang ada di sekolah bisa teratasi dengan baik khususnya terkait moderasi beragama.

Selain itu, melakukan kegiatan pembinaan kepada guru dalam hal mengembangkan kemampuan guru mengembangkan media dan alat bantu pembelajaran maka pengawas akan melakukan musyawarah dengan guru mata pelajaran. Di dalam musyawarah tersebut, pengawas pendidikan agaa Islam akan memberikan pembinaan dan bimbingan sehingga memudahkan guru untuk meningkatkan kemampuan dan menggunakan media pembelajaran. Upaya pembinaan yang dilakukan oleh pengawas dalam memberikan pembinaan dan contoh dalam kegiatan inovasi pembelajaran dalam kelas kepada guru melalui focus group discussion dan pengawas akan menyampaikan mengenai inovasi yang dapat dilakukan oleh guru dalam proses pembelajaran yang mengandung unsur moderasi beragama (Noor, 2020: 12).

Tanggung jawab pengawas yang begitu besar dan berat hendaknya menjadi pendorong bagi pengawas yang bersangkutan untuk meningkatkan wawasan kemampuan dan kemampuan profesional, serta menyadari sepenuhnya bahwa jabatan pengawas bukan sekedar memperpanjang masa kerja, akan tetapi jabatan yang menuntut kerja keras dan profesionalisme tinggi.

Kementerian Agama Kabupaten Banyumas seringkali mengumpulkan Pengawas PAI di semua jenjang untuk keselarasan visi, misi, dan tujuan serta selalu memahami bahwa tujuan utama pengawas adalah membina, membimbing, dan juga menjadi teman yang baik bagi semua guru PAI agar semua problematika yang ada di sekolah bisa teratasi dengan baik.

Berdasarkan wawancara peneliti dengan Bapak Amin Makruf, bahwa di SMA N 1 Purwokerto pengawas PAI selalu rutin mendatangi dan mengawasi seluruh kegiatan keagamaan yang dilaksanakan. Beliau mengatakan peran pengawas PAI juga sangat penting karena guru akan merasa selalu diberi solusi atas permsalahan yang muncul. Keberagaman agama yang ada di SMA N 1 Purwokerto juga menjadi salah satu alasan pengawaa selalu memantau seluruh program kegiatan keagamaan dan selalu menyampaikan pentingnya moderasi beragama di sekolah.

\section{Program Kerjasama Kementerian Agama Kabupaten Banyumas dengan Forum Kerukunan Umat Beragama (FKUB) dalam Impementasi Moderasi Beragama di Sekolah}

Forum Kerukunan Umat Beragama adalah forum yang didirikan oleh masyarakat dan diberikan fasilitas dari pemerintah yang ditujukan untuk membentuk, menjaga, serta menguatkan umat beragama dalam menjadin keakraban 
serta kemakmuran. Pembuatan FKUB dilandasi oleh Peraturan Bersama Menteri Dalam Negeri dengan Menteri Agama masing-masing No. 8 Tahun 2006 dan Nomor 9 Tahun 2006.

$$
\text { Peranan FKUB dalam }
$$

mempertahankan keakraban antar umat beragama sangatlah penting. Dengan program - program yang telah dilaksanakan FKUB benar - benar telah menjadi wadah bagi aspirasi dan permasalahan yang muncul. Di Kabupaten Banyumas sendiri FKUB banyak sekali peran yang menjadikan Kabupaten Banyumas menjadi Kabupaten dengan tingkat kerukunan mencapai 92\% (suarabanyumas.com). Dengan slogan "Beda Ning Rukun" FKUB Kabupaten Banyumas benar-benar fokus dalam menumbuhkan rasa keakraban antar umat beragama di Kabupaten Banyumas.

Forum Kerukunan Umat Beragama (FKUB) Kabupaten Banyumas tidak hanya mengadakan program atau kegiatan yang sasarannya kepada masayarakat, namun FKUB juga mengadakan program yang sasarannya adalah pelajar di sekolah. Program tersebut bernama "FKUB goes to school" yang diselenggarakan 1 (satu) tahun sekali. Dalam kegiatan pertama ini dilakukan, FKUB bekerjasama dengan Kementerian Agama yang difasilitasi oleh Badan Kesbangpol Banyumas melakukan pembinaan kepada 200 peserta yang merupakan siswa dari SMA, SMK, dan MA serta dihadiri oleh tokoh - tokoh lintas agama di SMA N Ajibarang. Kegiatan ini dilaksankan sebagai respon FKUB Banyumas terhadap masalah intoleransi, dan radikalisme agama di kalangan pelajar. Program ini bertujuan untuk menyebarkan nilai-nilai kebangsaan yang inklusif, meningkatkan kerukunan, serta menciptakan kehidupan yang damai pada kalangan pelajar di Kabupaten Banyumas. Sehingga pelajar menjadi pribadi yang humanis, pluralis dan nasionalis serta menjadi agen dalam menjaga, merawat dan mempertahankan Pancasila, NKRI, UUD 1945 dan Bhineka Tunggal Ika. Kemudian selanjutnya setelah dilaksanakan di SMA $\mathrm{N}$ Ajibarang, program $F K U B$ goes to school akan dilaksanakan di SMA N Jatilawang, SMA N Sumpiuh, SMA N Banyumas, SMA N Sokaraja dan SMA N 2 Purwokerto.

Sebagai follow up dari kegiatan ini FKUB Kabupaten Banyumas juga membentuk forum Solidaritas Siswa Lintas Iman (SSLI). Forum ini nantinya akan dijadikan tangan panjangnya FKUB di kalangan pelajar dalam rangka meningkatkan kerukunan antar umat beragama dan sebagai upaya menangkal gerakan-gerakan yang intoleran pada kalangan pelajar.

\section{d. Faktor Pendukung dan Penghambat Program Moderasi Beragama di Sekolah}

\section{Faktor Pendukung}

a) Adanya ikatan kuat yang terjalin antara Kementerian Agama Kabupaten Banyumas melalui seksi PAIS dengan Guru PAI yang ada di sekolah sehingga koordinasi menjadi mudah.

b) Profesionalisme guru PAI di sekolah yang baik sehingga guru cakap dalam menangani segala persoalan siswa terkait radikalisme serta terampil dalam menyampaikan dalam penyampaian moderasi beragama kepada siswa dengan metode yang baik dan menarik.

c) Pembinaan rutin kepada forum-forum kelompok kerja guru seperti FKG, KKG, dan MGMP sehingga koordinasi berjalan sepaham.

d) Penyelenggaraan ekstrakulikuler keagamaan yang berjalan dengan baik sehingga dalam kegiatan ini siswa lebih memahami perbedaan dan pentingnya kesatuan antar umat beragama.

e) Pengawasan kepada Guru PAI di sekolah yang dilakukan secara rutin sehingga tejalinnya komunikasi yang baik.

f) Kerjasama antara Kementerian Agama Kabupaten Banyumas dengan Forum Kerukunan Umat Beragama (FKUB) 
dalam mensosialisasikan program moderasi beragama di sekolah.

\section{Faktor Penghambat}

a) Kurangnya jumlah pengawas di tingkat Sekolah Dasar (SD) sehingga materi penyampaian moderasi beragama yang harusnya diajarkan sejak kecil kurang terealisasi.

b) Terbatasnya anggaran yang membuat pelaksanaan pembinaan terhadap guru PAI tidak bisa diikuti secara menyeluruh.

c) Belum adanya buku pedoman resmi dari Kementerian Agama Republik Indonesia sehingga tidak ada panduan pokok yang digunakan kepada siswa.

d) Masih terbatasnya jumlah guru non muslim untuk mengajarkan moderasi beragama kepada siswa sesuai agama yang dianut.

e) Kegiatan pembinaan biasanya bertepatan dengan jam guru mengajar sehingga biasanya kegiatan pembelajaran kosong.

\section{KESIMPULAN}

Berdasarkan penelitian ini, program moderasi beragama yang dicanangkan oleh Kementerian Agama Kabupaten Banyumas diimplementasikan melalui 5 hal yaitu Pembinaan kepada Guru Pendidikan Agama Islam (PAI) di sekolah, Pembinaan Ekstrakulikuler Keagamaan di sekolah, Pengampu Guru Pendidikan Agama Islam (PAI) di sekolah, Pengawasan Pendidikan Agama Islam (PAI) di sekolah, dan membangun kerja sama dengan Forum Kerukunan Umat Beragama (FKUB) Kabupaten Banyumas.

Peneliti dapat menyimpulkan bahwa program moderasi beragama yang dilaksanakan oleh Kementerian Agama Kabupaten Banyumas di lingkungan sekolah sudah cukup baik. Hal ini bisa dilihat dari hasil wawancara dengan guru PAI yang ada di sekolah bahwa kegiatan pembinaan kepada guru maupun siswa di sekolah terkait moderasi beragama sudah banyak membuat perubahan dan banyak mengatasi berbagai masalah atau konflik keagamaan. Maka tidak heran hasil survey yang dilansir dari suarabanyumas.com menyebutkan bahwa tingkat kerukunan yang ada di kabupaten banyumas mencapai $92 \%$.

\section{DAFTAR PUSTAKA}

Akhmadi, A. (2019). Moderasi Beragama Dalam Keragaman Indonesia. Jurnal Diklat Keagamaan, 13(2), 48.

Alam, M. (2017). Studi Implementasi Pendidikan Islam Moderat dalam Mencegah Ancaman Radikalisme di Kota Sungai Penuh Jambi. Jurnal Islamika, 17(2), 17-40.

Almu'tasim, A. (2019). Berkaca NU dan Muhammadiyah dalam Mewujudkan Nilai-Nilai Moderasi Islam di Indonesia. TARBIYA ISLAMIA: Jurnal Pendidikan dan Keislaman, 8(2), 199-212.

Amin, R.M. (2014). Prinsip dan fenomena Moderasi Islam Dalam Tradisi hukum Islam. Jurnal Al-Qalam, 20(1), 23.

Dawing, D. (2017). Mengusung Moderasi Islam di tengah Masyarakat Multikultural. Rausyan Fikr: Jurnal Studi Ilmu Ushuluddin dan Filsafat, 13(2), 225-255.

Hiqmatunnisa, H. \& Az-Zafi., A. (2020). Penerapan Nilai-nilai Moderasi Islam dalam Pembelajaran Fiqih Di PTKIN menggunakan Konsep Problem Based Learn", Jurnal JIPIS, 29(1), 29.

Kementrian Agama RI. (2015). Naskah Akademik Bagi Penyuluh Agama Puslitbang Kehidupan Keagamaan. Jakarta: Kemdikbud.

Latif, Y. (2014). Mata Air keteladanan Pancasila dalam Perbuatan. Jakarta: Mizan.

Ma'arif, A.S. (2012). Politik Identitas dan Masa Depan Pluralisme Kita. Jakarta: Yayasan Abad Demokrasi.

Nababan, R.Y. (2016). Pengaruh Pendidikan dan Pelatihan Kerja 
Terhadap Kinerja Karyawan PT. PLN (Persero) Area Manado", Jurnal Emba, 4(3), 45.

Noor, L.N.F. (2020). Peran Pengawas Pendidikan Agama Islam (PPAI) Dalam meningkatkan Kompetensi Guru PAI Di SMP Swasta Wilayah Kecamatan Sidoarjo Kabupaten Sidoarjo". MA'ALIM: Jurnal Pendidikan Islam, 1(1), 12.

Nur, A. \& Mukhlis. (2016). Konsep Wasathiyah Dalam Al-Quran (Studi Komparatif Antara Tafsir Al-Tahrir Wa At-Tanwir Dan Aisar At-Tafasir). Jurnal An-Nur, 4(2), 39.

PPIM UIN Jakarta. (2017). Redam Radikalisme Butuh Pendidikan Keagamaan Inklusif, Rabu, 8 November 2017 dari uinjkt.ac.id.

Purwanto, Y. dkk. (2019). Internalisasi Nilai Moderasi Melalui Pendidikan Agama Islam di Perguruan Tinggi Umum. EDUKASI: Jurnal Penelitian Pendidikan Agama dan Keagamaan, 17(2), 110-124.

Salim, H. (2012). Menggagas Pendidikan Agama Lintas Sekolah Berciri Khaskan Agama Yang Tidak Seagama. Dalam Jurnal -Analisis, 12(2), 17.

Suharto, B., dkk. (2019). Moderasi Beragama: dari Indonesia Untuk Dunia. Yogyakarta: LKIS Pelangi Aksara.

Sutrisno, E. (2019). Aktualisasi Moderasi Beragama di Lembaga Pendidikan. Jurnal Bimas Islam, 12(1), 341.

Wahyudi, D. \& Novita, K. (2021). Literasi Moderasi Beragama Sebagai Reaktualisasi "Jihad Milenial" Era 4.0. Moderatio: Jurnal Moderasi Beragama, 1(1), 28.

Yasid, A. (2010). Membangun Islam Tengah. Yogyakarta: Pustaka Pesantren.

Zamimah, I. (2018). Moderatisme Islam dalam Konteks Keindonesiaan. AlFanar, 1(1), 75- 90. 